\title{
Investigating the Effectiveness of the Performance Appraisal Process in the Egyptian Tourism Companies
}

\author{
Samar Kamel Saad \\ Tourism Studies Department \\ Faculty of Tourism and Hotels, Suez Canal University
}

\begin{abstract}
There is evidence that the process of performance appraisal has a considerable influence on organizational success and employees' attitude and behavior within the workplace. The present study examines the effectiveness of the performance appraisal process conducted in the Egyptian tourism companies. The results indicated that most companies use performance appraisal as a tool to enhance employees' performance rather than an "outcome distributer" tool for making promotion, merit pay or dismissing decisions. Further, the procedural justice of the performance appraisal process is, to a large extent, not guaranteed. The results, also, revealed that many companies conduct unproductive feedback sessions with low employee participation. The proposed conclusions and implications can provide managers with insights into the current practice of the appraisal process and how to enhance the benefits obtained from it.
\end{abstract}

Keywords: Performance Appraisal, Effectiveness, Medium and Large Sized Companies, Tourism, Egypt

\section{Introduction}

Performance appraisal forms a general heading for various management activities in organizations (Fletcher, 2001). According to Scott and Einstein (2001), it is a systematic process that focuses on the formal requirements of specified jobs, whether these requirements were related to outcomes, behavior or competency. It integrates organizational policies and human resource activities (Fletcher, 2001). Delery and Doty (1996) characterize performance appraisal as a strategic human resource (HR) practice that influences the overall performance of the organization. Management literature addressed the role of effective performance appraisal process in ensuring organizational success. For example, it increases employees' knowledge about how they are doing (Drucker, 2012), improves the accuracy of employees' performance (Locke and Latham,2002), links current performance with employees' goals (Fletcher, 2001), reduces employees' turnover (poon, 2004) and increases motivation (Kuvaas, 2006). However, it is widely believed that performance appraisal usually suffers from problems such as bias and inaccuracy, hindering its effectiveness (Banks and Roberson, 1985). Such problems create employees' feelings of inequity in assessments, unfairness of the process, job dissatisfaction, and intentions to quit (Poon, 2004), leading to the failure of the appraisal system (taylor et al., 1995). Therefore, this paper aims to explore the effectiveness of the performance appraisal process in the context of the Egyptian tourism companies. It aims to find answers to the following questions:

RQ1: How do employees in tourism companies perceive, interpret and make sense of their performance appraisal experiences?

RQ2: In what way can the employees' perception of appraisal experience lead to the design of more effective performance appraisal process?

In order to answer these questions, this study examines aspects that found to be well related to the effectiveness of the performance appraisal process. In particular, this study takes into account perceived goals of performance appraisal, criteria used, procedural justice, feedback, and employee participation in the feedback session.

\section{Literature Review}

\section{Performance appraisal process}

Dulewicz (1989) was one of the first authors to consider the use of performance appraisal in organizations. He stated that the idea of performance appraisal grew up from "the basic human tendency to make judgments about those one is working with, as well as about oneself". As an organizational gauging tool, it evaluates how well employees do their jobs and provides mangers with information related to performance management. It estimates employees' contributions to organizations' predefined goals during a period of time (Banks and Roberson 1985; Bretz et al., 1992; Fletcher, 2001). It is designed to enhance employees' performance by defining their performance weaknesses that need to be overcome (Drucker, 2012). Finally, it is used for making administrative decisions such as distributing rewards and promotions (Fletcher 2001). Within such process, supervisors and their employees have the opportunity to openly discuss the expectations of the organization versus the 
achievements of the employees (Roberts and Reed, 1996).An effective performance appraisal process should guide employees to the way of developing their performance and consequently lead to a continuous organizational success.

Prior research tends to link effective human resource management practices, such as performance appraisal, with better financial performance in organizations (Delery and Doty, 1996; Huselid, 1995). According to Zemke and Schaaf (2003), organizations which carried out performance appraisal process have increased their productivity by approximately $43 \%$. On the other hand, several researchers have studied such issue asserting the positive influence of the performance appraisal experience on the work environment (e.g. Mayer and Davis, 1999; Lawler, 1994; Giles and Mossholder, 1990; Taylor et al., 1995; Sudin, 2011). For example, it develops a favorable job, creates a feel of justice, motivates performance enhancement and increases employees' satisfaction. Satisfied, motivated employees were found to positively enhance organizational performance and accordingly increase customer satisfaction especially in services industry, such as tourism (Yoon et al., 2001). According to Chi and Gursoy (2009), there is an indirect relationship between employees' satisfaction and financial performance, mediated by customer satisfaction. This implies thatemployees' appraisal reactions (attitudes and behaviors) can lead any organization to its success or failure.

Despite such promising outcomes of performance appraisal process, there are some doubts of achieving them. Researchers found that the management of such process can adversely influence the accuracy, validity and accordingly the efficiency of its results. In instance, the validity of the performance appraisal is questionable if the criteria of the assessment is poor (Pan and Li, 2006; Ivancevich, 2004) and the technique used is complicated (Beer, 1987). Prior research indicated that supervisors' evaluations are often influenced by their social relationship with employees and feelings towards them (Barrick et al., 2009).Subjective feelings, such as bias, trust and sympathy, can distort the validity of the performance appraisal by increasing or decreasing the employees' rates. Given the complex nature of the tourism business, the performance goal of most of employees should be to do the job well in teamwork besides achieving customers' satisfaction. Evaluating individual's performance within teamwork is quiet difficult as teams' members are usually interdependent on each other in addition to other units of the organizations (Scott and Einstein, 2001; Kline and Sulsky, 2009). Moreover, employees' behavior and the quality of their customers' relation- which are significant factors influencing customer satisfaction-found to be poorly assessed in performance appraisals (Saad, 2013).Thus many organizations, as asserted by Fletcher (1997 and 2001), perceive performance appraisal as a time consuming and irrelevant process. In this respect, searching issues such as the effective management, support and development of the performance appraisal process has been a central concern for researchers of human resource management studies. Yet, there is a paucity of research examining such issues in the tourism literature, especially in the context of the Middle East countries. Therefore, this study aims to explore the aspects of the effective management of the performance appraisal process by investigating the context of the Egyptian tourism companies.

\section{Measuring the effectiveness of the performance appraisal}

Upon review, the effectiveness of the performance appraisal process is based mainly on its proper management. Researchers (e.g. Longenecker and Nykodym, 1996; Wright and Cheung, 2007) emphasized the role of effective planning, continues feedback and well performance monitoring by supervisors. Furthermore, according to Wright (2004), employees found appraisals to be more effective when they have more participation and control over the process. On the other hand, Wright (2004) argued that supervisors believed that the key to a successful performance appraisal process is to link it to organizational strategy. Another important component of an effective performance appraisal is the clear and measurable criteria used to appraise employee performance (Bobko and Colella, 1994; Wright and Cheung, 2007). This is complimented with the performance appraisal goals that should be specific, focused and obvious to the employees (Erez et al, 1985; Wright, 2004). Subsequent to the previous mentioned effectiveness factors, the employees' perception of the procedural justice found to be a crucial element in the success of the performance appraisal process. Such mentioned factors are clustered and explained in the following five sub-sections: "goal setting", "criteria", "procedural justice", "feedback", and "employee participation".

\section{Goal setting}

In general, performance appraisal goals should be understandable and clear so that the employees would simply focus on what to work towards (Locke and Latham, 2002). However, the dilemma here is not the transparency of the goals but the concept of them. According to Youngcourt and colleagues (2007), three core concepts are central to an effective goal setting: First, evaluating the appraisal outcomes in order to take decisions about issues such as pay increases, promotions, recruitment and retires. Second, enhancing employees' competencies and their personal development. Third, using the information obtained from the performance appraisal in analyzing the role breadth of different positions and then allocating the needed resources. Ahmed (1999) articulated that, practically, most organizations focus on the first traditional concept which supports other human resource management functions such as rewarding, disciplining and defining training needs. However, current research and viewpoints are strongly considering performance appraisal as an employee developmental tool that defines coaching/counseling needs, matches employees and organizational expectations to each other, and motivates employees along with the traditional goals (e.g. Ahmed, 1999; Fletcher, 2001; Kuvaas, 2006). The author supports that organizations should 
have a systematic framework to ensure that performance appraisal is a developmental procedure for both organizational and employees' performance. Performance appraisal should not be considered as an "outcomes distributer" tool for merit pay, promotion or status. It should not either be viewed as a punishment tool that deals with performance disagreement between managers and employees. Particularly, considering performance appraisal as a developmental tool can lay the ground for more satisfied and committed employees (Youngcourt et al., 2007) leading to positive contributions to organizational productivity and customer satisfaction (Lai Wan, 2007).

\section{Criteria of performance appraisal}

More recently, several noteworthy works have indicated the need to establish concrete criteria for evaluating employee performance (e.g. Babakus et al., 1996; Pettijohn, 2001; Locke and Latham, 2002). The criteria may be particular end goals, competencies, skills, characteristics, behaviors or any other element related to the job (Palaiologos et al., 2011). Whatever the criteria were, they should be clear and objective. The lack of clarity and objectivity of the criteria creates role ambiguity, confusion and frustration among the employees when doing their jobs (Palaiologos et al., 2011). It is, also, important for employees to be aware of the performance appraisal criteria early in their organizational life and clearly understand how to achieve those (Palaiologos et al., 2011). This will enable them to be well prepared for their performance evaluation. On the other hand, inconspicuous, vague criteria of evaluation make the employees feel that the performance appraisal process is unfair (e.g. Palaiologos et al., 2011). Employees who express such unconstructive feeling are more likely to develop negative workplace attitudes (Tang and Sarsfield-Baldwin, 1996; Poon, 2004; Kuvaas, 2006). For example, employee dissatisfaction, lack of organizational commitment, and turnover intention. These negative attitudes cause detrimental changes in individuals' behavior affecting their productivity. Unfortunately, such attitudes and behaviors spill over quickly within the workplace which as a result affect the organizational performance. Therefore, managers should consider the clarity of the performance appraisal's criteria and its fairness.

\section{Procedural justice}

Procedural justice refers to the fairness of the procedures of an organizational process (Tang and Sarsfield-Baldwin, 1996) regarding the framework, methods, or mechanisms used to achieve the targeted outcomes (Greenberg, 1986). Several organizational management researchers suggested control variables to assure procedural justice in the process of performance appraisal: (1) proper consideration of employees' viewpoint (Erez et al.; 1985); (2) bias control (Prendergast and Topel, 1993; Palaiologos, 2011); (3) steadiness of criteria across employees (Bobko and Colella, 1994); (4) timely feedback about the resulted decisions (Greenberg, 1986); (5) managers sincerity when communicating with employees (Mayer and Davis, 1999); (6) treating employees with gentleness (Sudin, 2011); (7)providing employees with rational explanation for a resulted decision (Mayer and Davis, 1999). All the previous variables found to play a critical role in assuring the procedural justice of the performance appraisal and consequently the employees' perception of fairness. According to the literature, a performance appraisal process in which fairness is embedded, ensures several positive employee-organizational attitudes such as employees' trust in the system (Dobbins et al., 1993; Pichler, 2012), job satisfaction and motivation (Lawler, 1994). Such positive attitudes are more likely to create a feeling of work commitment and thus increase employees' productivity. Therefore, procedural justice was found to be an important predictor to the effectiveness of the performance appraisal as well as the organizational system.

\section{Feedback}

The message of the performance appraisal feedback contains, first and foremost, the level of the performance rating the employee achieved (Klugerand Denisi, 1996). These rates will inform employees of how well they are doing and what improvements are needed. Therefore, the feedback message should be as timely as possible. The sooner the feedback was, the sooner the corrections of the unfavorable performance would be (Folger et al., 1992). Thus, feedback is believed of a great impact on organizational and employees' future performance. According to McCarthy and Garavan (2001), it influences performance management, career development, job satisfaction, and motivation. Although informing employees of their rates seems to be an easy step in the performance appraisal process, it requires a great caution. It is widely believed that employees' reactions to feedback depends on the level of rates they receive (e.g. Brett and Atwater, 2001). They react more positively when they have high rates. However, due to unfavorable performance, managers ought to give some employees negative feedback. Thus, it is expected that such employees would react negatively to the workplace. Moreover, some managers abuse the feedback session to destructively criticize employees with low rates (drucker, 2012) especially those at odds with each other. As Jawahar (2010) suggested, managers should be trained on how to conduct feedback discussions and guide employees to the best way to improve their performance. Such training should be used to motivate managers/supervisors to run the feedback session more accurately and in a positive manner (Jawahar,2010). It is also important that organizations highlight the value of feedback to build an effective appraisal, maximize its benefits and avoid the dysfunctional practices for the organization. 
Employee participation

Employee participation in the performance appraisal process is a crucial element in achieving long-term effectiveness of the system (Cawley et al., 1998; Roberts, 2003). Participation makes employees feel that they have a voice and control through the performance appraisal process (Wright, 2004). This creates involvement and motivation values within the organization, leading employees to increase productivity and contribute in various workplace aspects (Roberts, 2003). Moreover, participation enables employees to share knowledge with coworkers and managers encouraging a sense of teamwork in organizations (Cotton, 1993; Roberts, 2003).Prior research on performance appraisal argued that employees' participation takes different forms in such process: participation in the appraisal interview, participation in setting goals, employees' opportunity to explain their side of the issue, the level of influence the employees believe they can make when voicing their opinion, making self-appraisal, and contributing in the enhancement of the appraisal system (e.g. Cawley et al., 1998; Roberts and Reed, 1996). The absence of any of the previous forms is likely to close the lines of communication between managers and employees. Moreover, according to Roberts (2003), low employee participation increases the probability of an ineffective performance appraisal process. It, also, provokes the employees to see the process as useless (Wright, 2004).

\section{Methodology}

\section{Sample}

The current study took place during the third quarter of 2014 and the data were collected using questionnaires that were personally distributed. Participants were employees of $\leqslant$ medium and large size tourism companies, which were all located in the greater Cairo region. The criteria for including a company or an employee in this sample were as follows. First, the company should have a department of HR and the performance appraisal process should be conducted for over three years. Second, employees are accepted in the sample only if they had been evaluated at least twice during their work experience. In addition, the number of participants from each company ranges from 7 to 10 in order to avoid the underrepresentation or overrepresentation of certain companies. Such criteria were chosen in order to ensure the validity of the results. However, this influenced the size of the sample as the pilot study highlighted the irregular implementation of the appraisal process in many of tourism companies in Egypt. The size of this sample is 383 usable questionnaires, with a response rate of about 87 per cent. The majority of the employees in this sample found to be evaluated once a year.

\section{Measures}

The questionnaire was designed based on a range of related studies (Youngcourt et al., 2007; Colquitt JA, 2001; Pooyan and Eberhardt, 1989;Giles and Mossholder, 1990). Its final form included 31 questions. These questions were translated into Arabic to avoid misunderstanding of specific terms. The first part of the questionnaire consisted of demographic information, while the second part included the following 5 variables influencing the effectiveness of the performance appraisal process:

Setting goals: seven items were used to assess participants' perception on performance appraisal goals, adopted from Youngcourt et al. (2007), such as "performance appraisal helps determine whether to promote, retain or terminate an employee" and "performance appraisal determines what raise someone should receive". Participants used a seven-point Likert scale ranging from "I strongly disagree" to "I strongly agree" to respond to the items.

Procedural justice: the instrument used to measure participants' perception of procedural justice was adopted from Colquitt (2001), such as "Have the performance appraisal procedures been based on accurate information?" and "Have the performance appraisal procedures been applied consistently?". A seven-point Likert scale ranging from "I strongly disagree" to "I strongly agree" was adopted.

Criteria: the same items used by Pooyan and Eberhardt (1989) to measure performance appraisal criteria were used in this study, such as "results I achieved" and "my job related behaviors". A five-point Likert scale ranging from "never" to "every time" was utilized.

Feedback: the instrument used to measure feedback was adopted from Giles and Mossholder's (1990). For example, questions included were: "I felt quite satisfied with my last review discussion" and "My last appraisal feedback interview gave me a good idea of how well I'm doing my job". A seven-point Likert scale ranging from "I strongly disagree" to "I strongly agree" was used. In this survey the researcher added a new item: "no feedback discussion has been held between my manager and I". The respondents were informed that when their answer is "strongly agree", they should stop answering the rest of the questions.

Employee participation: the instrument used to measure the participants' perception of their participation in the feedback discussion was adopted from Giles and Mossholder's (1990), for example, questions included were: "I was given the opportunity to participate in feedback discussion" and "My manager asked me to share my views about my performance". A seven-point Likert scale ranging from "I strongly disagree" to "I strongly agree" was adopted. 


\section{Results}

The findings of this study have been organized according to the following five variables:

The results of "setting goals" variable: table 1 showed the frequencies of respondents' ranks of the setting goals variable. When analyzing the findings, it was revealed that the majority of respondents rated three items as "disagree". These items were related to the role of performance appraisal in promoting, retaining or terminating an employee and determining the raise that someone should receive (see table 1). However, the other four items received more than $48 \%$ of respondents choosing "agree" as a rank. These items were related to the role of performance appraisal in documenting and recognizing employee performance, letting employees know where they stand, providing feedback about employee performance and identifying individual strength and weaknesses.

Table (1): percentages of respondents' ranks of their perception on "setting goals", "procedural justice", "feedback", and "employee participation"

\begin{tabular}{|c|c|c|c|c|c|c|c|}
\hline Variables & 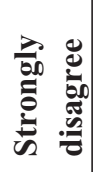 & 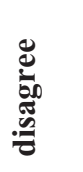 & 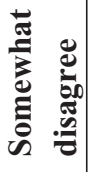 & 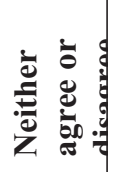 & 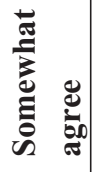 & 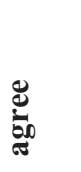 & 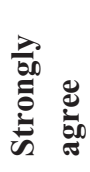 \\
\hline \multicolumn{8}{|l|}{ Setting goals } \\
\hline $\begin{array}{l}\text { performance appraisal helps determine whether to } \\
\text { promote, retain or terminate an employee }\end{array}$ & 20.9 & 52.0 & 14.9 & 6.8 & 0.8 & 3.1 & 1.6 \\
\hline $\begin{array}{l}\text { performance appraisal determines what raise someone } \\
\text { should receive }\end{array}$ & 23.5 & 38.4 & 27.4 & 4.7 & 1.6 & 1.6 & 2.9 \\
\hline $\begin{array}{l}\text { performance appraisal process documents and } \\
\text { recognizes employee performance }\end{array}$ & 2.6 & 41.0 & 34.7 & 1.8 & 6.0 & 8.4 & 5.5 \\
\hline $\begin{array}{l}\text { Performance ratings let employees know where they } \\
\text { stand }\end{array}$ & 0.0 & 0.0 & 0.0 & 5.7 & 18.5 & 48.8 & 26.9 \\
\hline $\begin{array}{l}\text { Performance ratings are used to provide feedback } \\
\text { about employee performance }\end{array}$ & 2.3 & 2.9 & 5.5 & 1.3 & 14.4 & 48.8 & 27.2 \\
\hline $\begin{array}{l}\text { Performance ratings identify individual strength and } \\
\text { weaknesses }\end{array}$ & 1.3 & 7.0 & 6.5 & 5.7 & 9.9 & 54.6 & 14.9 \\
\hline \multicolumn{8}{|l|}{ Procedural justice } \\
\hline $\begin{array}{l}\text { Have the performance appraisal procedures been based } \\
\text { on accurate information? }\end{array}$ & 2.1 & 2.9 & 66.6 & 1.6 & 17.8 & 5.0 & 4.2 \\
\hline $\begin{array}{l}\text { Have the performance appraisal procedures been } \\
\text { applied consistently? }\end{array}$ & 7.0 & 2.9 & 9.7 & 0.0 & 8.9 & 23.0 & 48.6 \\
\hline $\begin{array}{l}\text { Have the performance appraisal procedures been free } \\
\text { of bias? }\end{array}$ & 17.2 & 20.4 & 49.1 & 2.1 & 5.5 & 3.1 & 2.6 \\
\hline $\begin{array}{l}\text { Have you been able to appeal the outcome arrived at } \\
\text { by those procedures? }\end{array}$ & 7.0 & 37.6 & 29.0 & 6.0 & 9.1 & 4.2 & 7.0 \\
\hline
\end{tabular}




\begin{tabular}{|l|r|r|r|r|r|r|r|}
\hline $\begin{array}{l}\text { Have the performance appraisal procedures upheld } \\
\text { ethical and moral standards? }\end{array}$ & 3.9 & 28.7 & 37.1 & 12.8 & 8.9 & 5.2 & 3.4 \\
\hline feedback & & & & & & & \\
\hline $\begin{array}{l}\text { no feedback discussion has been held between my } \\
\text { manager and I }\end{array}$ & 9.7 & 36.0 & 5.0 & 0.0 & 8.1 & 9.9 & 31.3 \\
\hline I felt quite satisfied with my last review discussion & 2.1 & 11.5 & 15.7 & 31.3 & 21.4 & 11.0 & 7.0 \\
\hline $\begin{array}{l}\text { My last appraisal feedback interview gave me a good } \\
\text { idea of how well I'm doing my job }\end{array}$ & 3.1 & 4.4 & 15.7 & 31.3 & 34.5 & 6.0 & 5.0 \\
\hline $\begin{array}{l}\text { The appraisal feedback helped me learn how I can do } \\
\text { my job better }\end{array}$ & 7.0 & 9.9 & 7.0 & 31.3 & 37.1 & 6.0 & 1.6 \\
\hline Employee participation & 14.4 & 11.5 & 25.1 & 31.3 & 8.9 & 5.0 & 3.9 \\
\hline $\begin{array}{l}\text { I was given the opportunity to participate in feedback } \\
\text { discussion }\end{array}$ & 11.5 & 8.6 & 6.8 & 31.3 & 33.2 & 5.7 & 2.9 \\
\hline $\begin{array}{l}\text { My manager asked me to share my views about my } \\
\text { performance }\end{array}$ & 2.6 & 5.5 & 37.3 & 31.3 & 10.4 & 6.0 & 6.8 \\
\hline $\begin{array}{l}\text { Whenever there was a disagreement my manager gave } \\
\text { me chance to explain my views }\end{array}$ & 3.1 & 34.7 & 31.3 & 20.4 & 3.1 & 3.1 \\
\hline $\begin{array}{l}\text { I was given the opportunity to state my side of all the } \\
\text { issues discussed during my performance review }\end{array}$ & 2.3 & 17.5 & 35.0 & 31.3 & 2.9 & 7.8 & 3.1 \\
\hline $\begin{array}{l}\text { I was given the opportunity to discuss all aspects of my } \\
\text { job during my performance review }\end{array}$ & 4.2 & & & & & \\
\hline
\end{tabular}

The results of Procedural justice variable: the findings of this section revealed the extent to which respondents think the procedures of the performance appraisal are fair. The notable result is that all items except one seemed to be perceived as quiet unfair. For example, the majority of respondents ranked "Have the performance appraisal procedures been based on accurate information?" as somewhat disagree (66.6\%), "Have the performance appraisal procedures been free of bias?" as somewhat disagree (49.1\%), "Have you been able to appeal the outcome arrived at by those procedures?" as disagree (37.6\%), "Have the performance appraisal procedures upheld ethical and moral standards?" as somewhat disagree (37.1\%) and "Have you been informed with the appraisal rates" as disagree (51.2\%). However, respondents ranked the item "Have the performance appraisal procedures been applied consistently?" as strongly agree (48.6\%) (see table 1).

The results of criteria variable: this section aimed to gain an understanding of the kind of criteria used to appraise employees in Egyptian tourism companies. It was found that the majority of respondents see that all items are almost used in every performance appraisal with very few respondents (less than 5\%) choosing "never used for measurement" (see table 2). 
Table (2): percentages of respondents' ranks of the use of indicated criteria

\begin{tabular}{|l|l|l|l|l|l|}
\hline Variable & & & & & \\
& & & & & \\
& & & & & \\
\hline criteria & & & & & \\
\hline results I achieved & 1.8 & 3.1 & 20.6 & 48.8 & 25.6 \\
\hline my job related behaviors & 2.9 & 7.0 & 32.1 & 51.7 & 6.3 \\
\hline my skills and abilities & 1.3 & 6.0 & 21.1 & 43.1 & 28.5 \\
\hline my personality and personal & & & & & \\
characteristics & 1.8 & 3.1 & 24.5 & 46.5 & 24.0 \\
\hline things I can control & 4.2 & 6.3 & 30.0 & 38.1 & 21.4 \\
\hline predetermined goals & 2.9 & 3.9 & 28.7 & 36.0 & 28.5 \\
\hline general impressions & 3.4 & 6.0 & 11.5 & 49.1 & 30.0 \\
\hline
\end{tabular}

The results of feedback variable: table 1 shows the frequencies of respondents' ranks on the feedback variable. The first notice is that a considerable percentage of respondents ranked the item "no feedback discussion has been held between my manager and I" as strongly agree (31.3\%), while $36 \%$ of respondents ranked the same item as disagree. The second notice is that the majority of respondents who have a feedback session (36\%) ranked the rest of the items as somewhat agree. These items are "I felt quite satisfied with my last review discussion" (21.4\%), "My last appraisal feedback interview gave me a good idea of how well I'm doing my job" (34.5\%) and "The appraisal feedback helped me learn how I can do my job better" $(37.1 \%)$.

The results of Employee participation variable: this section aimed to measure employees' satisfaction of their participation in the feedback session. Table 1 shows that the item "II was given the opportunity to participate in feedback discussion" received (25.1\%) as somewhat disagree, "My manager asked me to share my views about my performance" received (33.2\%) as somewhat agree, "Whenever there was a disagreement my manager gave me chance to explain my views" received $(37.3 \%)$ as somewhat disagree, "I was given the opportunity to state my side of all the issues discussed during my performance review" received (35\%) as somewhat q disagree, and "I was given the opportunity to discuss all aspects of my job during my performance review" received (34.7\%) as somewhat disagree.

\section{Discussion}

This study explored employees' perception of the effectiveness of the performance appraisal process in the context of the Egyptian tourism companies. According to Jawaher (2010), the success of the appraisal process is well likely to depend on rates' perceptions of justice besides reactions to essential aspects of the appraisal process. Traditionally, Prior studies focus on the motivational influence that an effective performance appraisal can have on employees in the workplace (e.g. Mayer and Davis, 1999; Lawler, 1994). For instance, it develops a favorable job, creates a feeling of justice, evokes performance enhancement and increases employees' satisfaction (e.g. Giles and Mossholder, 1990; Taylor et al., 1984; Sudin, 2011). Five factors, found to be linked to the effectiveness of the performance appraisal process, were considered in this study: "goal setting", "procedural justice", "performance criteria", "feedback", and "employee participation in feedback session".

The findings of this study support that Employees in Egyptian tourism companies are able to clearly understand the goals of the performance appraisal process. It seems that employees know what to work towards. Performance appraisal quite enables employees to understand their strength and weakness points in their performance, thus, take actions to enhance it. According to Locke and Latham (2002), this knowledge may well eliminate job ambiguity which is a source of stress in the workplace. However, and inconsistent with Ahmed's study (1999), the results show that the outcome data during the 
performance appraisal process are not a requirement for taking decisions related to payroll, promotion and employment termination; the traditional goal of performance appraisal. It seems that taking such decisions in the sampled organizations does not depend on performance appraisal outcomes as a primary source of data. Therefore, the study suggests that most of the Egyptian tourism companies tend to use performance appraisal as a tool for developmental purposes rather than for setting human resources budget, allocating resources, promoting or laying employees off.

Moreover, the results revealed that most of the Egyptian organizations use different set of criteria for their performance appraisal. As previously mentioned, the criteria usually include the end goals that employees must achieve, their behavior within the workplace, their skills, their personal characteristics and their level of control on their duty (Pooyin and Eberhardth, 1989). It is obvious that the criteria of performance appraisal in the sampled organizations do not focus on specific items rather than others. Such Varity in the set of criteria decreases employees' feeling of inequality in the evaluation process (Palaiologos et al., 2011). Furthermore, this may well create a sense of satisfaction with the appraisal (Pooyin and Eberhardth, 1989).

As the study continues, significant indicators related to the employees' perception of the procedural justice of the appraisal process were observed. The results confirm that a significant number of the participants experiences feelings of worry towards the justice of the procedures used in the appraisal process. Issues such as depending on accurate information, free of bias, the chance of appealing the process outcomes, ethical and moral standards of the process, and timely feedback are negatively perceived by most of the employees. By their nature, such issues play a critical role in assuring the procedural justice of the performance appraisal and consequently the employees' perception of fairness (see Palaiologos, 2011; Bobko and Colella, 1994; Greenberg, 1986). In light of Dobbins and colleagues' study (1993) and Lawler's study (1994), employees' perception of an unfair process has a significant negative relation with employees' trust in the system, satisfaction and motivation. Therefore, an unfair appraisal process may represent the base of many negative attitudes in the workplace. Given that, it is imperative to more fully understand why many of the tourism companies in Egypt tune out the procedural justice of the appraisal process, hindering the equal evaluation of employees, damaging their social workplace environment. It is also important to define whether such injustice procedures were deliberate or not.

Moreover, the results show that employees perceive the appraisal feedback as less productive than it should be. They believe that the feedback session misses important features. For example, full information about the actual evaluation of employees' performance and information about how to improve such performance. This cultivates a feeling of dissatisfaction with the session. Moreover, many of the participants confirmed that they have never had an appraisal feedback discussion with their supervisor. Others highlighted that the feedback session is not implemented periodically. This indicates that many of the supervisors pay little attention to conducting a feedback session despite its critical importance to the company and its employees. Past research has shown that a productive feedback session positively influences employee's attitudes in the organizations, for example, performance management, career development, job satisfaction, and motivation (McCarthy and Garavan, 2001). Therefore, and consistent with McCarthy and Garavan (2001) and Jawahar (2010), These findings reinforce the need for the Egyptian tourism companies to consider the importance of positively introducing and implementing feedback in order to enhance the benefits derived from the appraisal process.

Also, participants who indicated having a feedback session significantly experienced an increase in participation dissatisfaction. In other words, the chance given to them to discuss the appraisal results and express their view points about the performance was to the minimal. According to Wright (2004), this evokes employees to see the whole appraisal process as unfair and unacceptable, creating undesirable attitudes towards workplace such as job dissatisfaction and low involvement (Roberts, 2003).

\section{Conclusion and implications for practitioners}

The present study examines the effectiveness of the performance appraisal process conducted in the Egyptian tourism companies. Since performance appraisal is one of the most complex human resource management practices, its effective implantation is important for managers and employees. The results lead to some recommendations for practitioners that can be summarized in the following paragraphs.

First, it is important for tourism companies to fully understand why they need to conduct a performance appraisal process as a starting point. As was revealed from the results, Egyptian tourism companies usually conduct the appraisal process without benefiting from its outcomes in making evaluation related-decisions such as payroll, promotions or dismissing. They do not either gain the full developmental benefits of the appraisal process such as correcting, guiding and enhancing employees performance. Therefore, organizations should thoroughly understand the goals and benefits that can be gained from such process. The study recommends that top managers develop the appraisal goals and criteria that can be linked to the overall strategy of the organization. This will help planning, designing and conducting the performance appraisal in a cost effective way. 
Ensuring procedural justice can lead to an increased transparent process and accordingly a more satisfied employee. More specifically, implementing the performance appraisal process should be based on the appraisal standards that guarantee information disclosure, clarity and accuracy. Perceptions of procedural unfairness can negatively affect employees' organizational commitment, job satisfaction, trust in management and performance (see Dobbins et al., 1993; Tang and Sarsfield-Baldwin, 1996; Mayer and Davis, 1999; Pichler, 2012). Therefore, the Egyptian tourism companies should recruit managers who are likely to be perceived as procedurally fair. Specialized training courses should also be conducted for managers who need to improve the procedural justice related skills. In addition, it will be beneficial when top managers regularly monitor the relations between performance appraisal ratings and related outcomes (e.g. promotions), and indicators of employees' performance such as productivity and quality measures. This would help controlling managers' bias and other unethical manners when rating employees.

Finally, conducting unproductive feedback sessions with low employee participation has a great effect on the employees' attitude in the company. Apparently, managers' role in managing the feedback session is fundamental, as they seem to be the main responsible of introducing high or low quality feedback sessions. The results once again highlight the importance of training managers for feedback sessions, and encourage them to positively communicate with their subordinates. It is also required to conduct such feedback session at a regular certain time with all needed information about employees' current and targeted performance.

The present study attempts to add to the tourism literature by investigating the effectiveness of the performance appraisal process in the context of the Egyptian tourism companies. There are two limitations of this study; first, this study tested perceptual data from - only-employees' perspective. In this respect, future research may need to include and compare data from other perspectives, e.g. managers. This is to have insights to how different stakeholders' views on performance appraisal process can influence successful performance of tourism companies. Second, since the current study took place in Egypt, the findings may not be generalized to other Middle Eastern countries. Still, future research needs to enrich our understanding of the effectiveness of performance appraisal process by investigating different contexts.

\section{Reference}

Ahmed, S. (1999). The emerging measure of effectiveness for human resource management: An exploratory study with performance appraisal. Journal of management development, 18(6), 543-556.

Babakus, E., Cravens, D.W., Johnston, M. and Moncrief, W.C. (1996), Examining the role of organizational variables in the salesperson job satisfaction model, Journal of Personal Selling and Sales Management, Vol. 16 No. 3, pp. 33-46.

Banks CG and Roberson L (1985). Performance appraisers as test developers. Acad Manage Rev 10:128-142

Barrick, M., Shaffer, J., \&DeGrassi, S. (2009). What you see may not be what you get: Relationships among self-presentation tactics and ratings of interview and job performance. Journal of Applied Psychology, 94(6), 1394-1411.

Beer, M. (1987), Performance appraisal, in Lorch, J. (Ed.), Handbook of Organizational Behavior, Prentice Hall, Englewood Cliffs, NJ, pp. 286-99.

Bies, R. J., \&Moag, J. S. (1986). Interactional justice: Communication criteria of fairness. Research on negotiation in organizations, 1(1), 43-55.

Bobko, P. and Colella, A. (1994), Employee reactions to performance standards: a review and research proposition, Personnel Psychology, Vol. 47, pp. 1-30.

Brett, J. F., \& Atwater, L. E. (2001). 360degrees feedback: Accuracy, reactions, and perceptions of usefulness. Journal of Applied Psychology, 85, 930-942.

Bretz, R.D. Jr, Milkovich, G.T. and Read, W. (1992), The current state of performance appraisal research and practice: concerns, directions, and implications, Journal of Management, Vol. 18 No. 2, pp. 321-52.

Cawley, B. D., Keeping, L. M., \& Levy, P. E. (1998). Participation in the performance appraisal process and employee reactions: A meta-analytic review of field investigations. Journal of applied psychology, 83(4), 615.

Chi, C. G., \&Gursoy, D. (2009). Employee satisfaction, customer satisfaction, and financial performance: An empirical examination. International Journal of Hospitality Management, 28(2), 245-253.

Colquitt, J. A. (2001). On the dimensionality of organizational justice: a construct validation of a measure. Journal of applied psychology, 86(3), 386.

Cotton, J. L. (1993). Employee involvement: Methods for improving performance and work attitudes. Sage Publications, Inc. 
Delery, J.E. and Doty, D.H. (1996), "Modes of theorizing in strategic human resource management: tests of universalistic, contingency, and configurational performance predictions", Academy of Management Journal, Vol. 39 No. 4, pp. 802-35.

Dobbins, G. H., Platz, S. J., \& Houston, J. (1993). Relationship between trust in appraisal and appraisal effectiveness: A field study. Journal of Business and Psychology, 7(3), 309-322.

Drucker, P. (2012). Management.Routledge.

Dulewicz, V. (1989). Performance appraisal and counselling, in Herriot, P., Assessment and selection in organizations: methods and practices for recruitment and appraisal, John Wiley \& Sons, New York, pp645-649

Erez, M., Earley, P.C. and Hulin, C.L. (1985), The impact of participation on goal acceptance and performance: a two-step model, Academy of Management Journal, Vol. 28, pp. 50-66.

Fletcher, C. (1997), Appraisal: Routes to Improved Performance, Chartered Institute of Personnel \& Development, London.

Fletcher, C. (2001). Performance appraisal and management: the developing research agenda. Journal of Occupational and Organizational Psychology, 74: 473-87.

Folger, R., Konovsky, M., \&Cropanzano, R. (1992).A due process model of performance appraisal.In B. M. Staw\& L. L Cummings (Eds.), Research in organizational behavior (Vol. 14, pp. 129-177). Greenwich, CT: JAI Press.

Giles, W.F. and Mossholder, K.W. (1990), "Employee reactions to contextual and session components of performance appraisal”, Journal of Applied Psychology, Vol. 75 No. 4, pp. 371-7.

Greenberg, J. (1986). Determinants of perceived fairness of performance evaluations.Journal of applied psychology, 71(2), 340.

Huselid, M.A. (1995), The impact of human resource management practices on turnover, productivity, and corporate financial performance, Academy of Management Journal, Vol. 38 No. 3, pp. 635-72.

Ivancevich, J.M. (2004), Human Resource Management, Irwin/McGraw-Hill, New York, NY, pp. 255-87.

Jawahar, I. M. (2010).The mediating role of appraisal feedback reactions on the relationship between rater feedback-related behaviors and ratee performance. Group \& Organization Management, 35(4), 494-526.

Kline, T. J., \&Sulsky, L. M. (2009).Measurement and assessment issues in performance appraisal.Canadian Psychology/Psychologiecanadienne, 50(3), 161.

Kluger, A. N., \&DeNisi, A. (1996). The effects of feedback interventions on performance: a historical review, a meta-analysis, and a preliminary feedback intervention theory. Psychological bulletin, 119(2), 254.

Kuvaas, B. (2006). Performance appraisal satisfaction and employee outcomes: mediating and moderating roles of work motivation. The International Journal of Human Resource Management, 17(3), 504-522.

Lai Wan, H. (2007), Human capital development policies: enhancing employees' satisfaction,Journal of European Industrial Training, Vol. 31 No. 4, pp. 297-322.

Lawler, E.E. (1994), Motivation in Work Organizations, Jossey-Bass, San Francisco, CA.

Locke, E.A. and Latham, G.P. (2002),Building a practically useful theory of goal setting and task motivation, American Psychologist, Vol. 57 No. 9, pp. 705-17.

Longenecker, C. O., \&Nykodym, N. (1996). Public sector performance appraisal effectiveness: A case study. Public Personnel Management, 25(2), 151-164.

Mayer, R. C., \& Davis, J. H. (1999). The effect of the performance appraisal system on trust for management: A field quasiexperiment. Journal of applied psychology, 84(1), 123.

McCarthy, M.A. and Garavan, N.T. (2001), 360 feedback processes: performance improvement and employee career development, Journal of European Industrial Training, Vol. 25 No. 1, pp. 5-32.

Moussavi, F., \&Ashbaugh, D. L. (1995). Perceptual effects of participative, goal-oriented performance appraisal: A field study in public agencies. Journal of Public Administration Research and Theory, 5(3), 331-343.

Palaiologos, A., Papazekos, P., \&Panayotopoulou, L. (2011).Organizational justice and employee satisfaction in performance appraisal. Journal of European Industrial Training, 35(8), 826-840. 
Pan, J. and Li, G. (2006), What can we learn from performance assessment? The system and practice in an academic library, Library Management, Vol. 27 Nos 6/7, pp. 460-9.

Pettijohn, S.L. (2001), Performance appraisals: usage, criteria and observations, Journal of Management Development, Vol. 20 No. 9, pp. 754-71.

Pichler, S. (2012). The social context of performance appraisal and appraisal reactions: A meta-analysis. Human Resource Management, 51(5), 709-732.

Poon, J. M. (2004).Effects of performance appraisal politics on job satisfaction and turnover intention. Personnel review, $33(3), 322-334$.

Pooyan, A. and Eberhardt, B.J. (1989), Correlates of performance appraisal satisfaction among supervisory and nonsupervisory employees, Journal of Business Research, Vol. 19 No. 3, pp. 215-26.

Prendergast, C., \&Topel, R. (1993).Discretion and bias in performance evaluation. European Economic Review, $37(2), 355$ 365.

Roberts, G. E. (2003). Employee performance appraisal system participation: A technique that works. Public Personnel Management, 32(1), 89-98.

Roberts, G. E. and T. Reed (1996).Performance Appraisal Participation, Goal Setting and Feedback: TheInfluence of Supervisory Style, Review of Public Personnel Administration, volume 16, 29-60.

Saad, S. K. (2013). Contemporary Challenges of Human Resource Planning in Tourism and Hospitality Organizations: A Conceptual Model. Journal of Human Resources in Hospitality \& Tourism, 12(4), 333-354.

Scott, S. G., \& Einstein, W. O. (2001). Strategic performance appraisal in team-based organizations: One size does not fit all. The Academy of Management Executive, 15(2), 107-116.

Sudin, S. (2011).Fairness of and satisfaction with performance appraisal process. Journal of Global Management, 2(1), 6683.

Tang, T. L. P., \&Sarsfield-Baldwin, L. J. (1996).Distributive and Procedural Justice as Related to Satisfaction and Commitment.

Taylor, S.M., Tracy, K.B., Renard, M.K., Harrison, J.K. and Carroll, S.J. (1995), Due process in performance appraisal: a quasi-experiment in procedural justice, Administrative Science Quarterly, Vol. 40, pp. 495-523.

Wright, R. (2004), Mapping cognitions to better understand attitudinal and behavioral responses in appraisal research, Journal of Organizational Behavior, Vol. 25 No. 3, pp. 339-74.

Wright, R. \& Cheung, F. K. (2007). Articulating appraisal system effectiveness based on managerial cognitions. Personnel Review, 36(2), 206-230.

Yoon, M.H., Sharon, E.B., Jaeboem, S. (2001). The effect of work climate on critical employee and customer outcomes. International Journal of Service Industry Management 12 (5), 500-521.

Youngcourt, S.S., Leiva, P.I. and Jones, R.G. (2007), Perceived purposes of performance appraisal: correlates of individual and positions - focused purposes on attitudinal outcomes, Human Resource Development Quarterly, Vol. 18 No. 3, pp. 315-43.

Zemke, R., and Schaaf, D. (2003).The service edge.Incentive, 177(4).

\section{التحقق من فعالية عملية تقييم الأداء في الشركات السياحية المصرية}

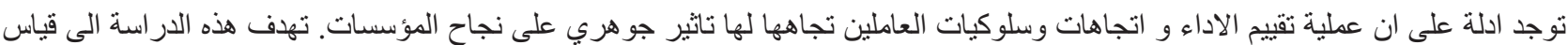

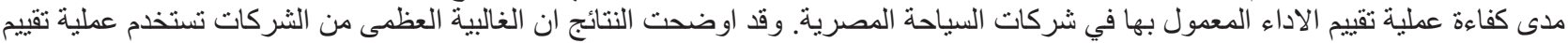

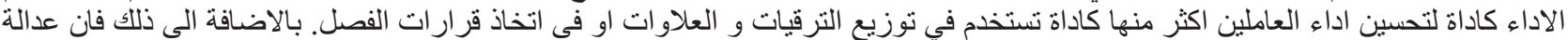

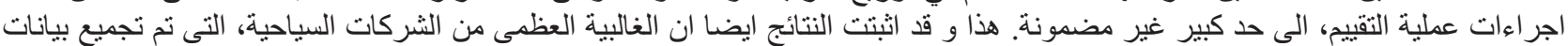

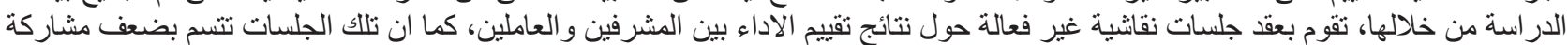

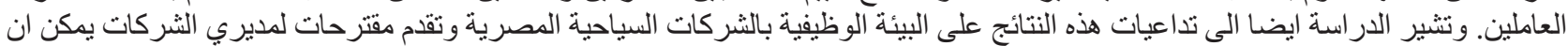

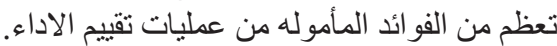

